\title{
Stomach content analysis and length-weight relationship of the Pontic shad Alosa immaculata Bennett, 1835 (Pisces: Clupeidae), from the eastern Black Sea coast of Turkey
}

\author{
RAHSAN EVREN MAZLUM AND SEVKIYE AKGUMUS \\ Recep Tayyip Erdogan University, Faculty of Fisheries, 53100, Rize, Turkey \\ e-mail:evren.mazlum@erdogan.edu.tr
}

\begin{abstract}
Diet composition of the anadromous Pontic shad Alosa immaculata Bennett, 1835 was studied in relation to season and body size, from samples collected from the south-east Black Sea coast of Turkey in spring, autumn and winter during the period from March 2012 - February 2013. Out of 236 samples, 226 stomachs contained food and 24 prey items were identified. Nematoda sp. and teleosts were the main prey items with index of relative importance (IRI) of 59.3 and $38.2 \%$ respectively. Seasonal analysis showed that the IRI of Nematoda sp. was $71.6 \%$ in winter, $50.6 \%$ in spring and $37.1 \%$ in autumn. The stomachs of fishes in the length range of $12.0-19.9 \mathrm{~cm}$ contained a higher proportion of Nematoda sp. (IRI up to $74-80 \%$ ). Larger fishes in the length range of 24.0-32.8 cm consumed more teleosts ( $>45 \%$ IRI) than the others. The length-weight relationship showed that females grow in positive allometric pattern while males have isometric growth.
\end{abstract}

Keywords: Alosa immaculata, Diadromous, Feeding ecology, Length-weight relationship, Nematoda, Pontic shad

\section{Introduction}

Shads (Family:Clupeidae) are economically important fishes with a signifcant role in the food web as prey item of other piscivorous fish (Juanes et al., 1993; Aprahamian et al., 2003). They are commercially harvested in the Danube River, Black and Azov Seas (Navodaru and Waldman, 2003; Raykov and Triantaphyllidis, 2015; TUIK, 2015). Three species of shads (Caspian shad Alosa caspia; Black Sea shad, Alosa maeotica and Pontic shad Alosa immaculata) are found in the Black Sea (Lenhardt et al., 2012). In Turkey, the total catch volume of shads was $2,581.5 \mathrm{t}$ in 2011 that decreased by $21.2 \%$ to $2,034.7 \mathrm{t}$ in 2015 (TUIK, 2015). Data from NAFA (National Agency for Fisheries and Aquaculture) showed a decrease of $65 \%$ in the share of $A$. immaculata to the total fish production of Bulgaria from 2010 to 2012 (Raykov and Triantaphyllidis, 2015). The population of $A$. immaculata in the Black and Azov seas has been shrinking since the last decade due to exploitation and pollution, including the construction of dams that prevent their access to rivers for spawning and nursery grounds (Freyhof and Kottelat, 2008). In Hungary, it is regionally extinct and hence listed as a vulnerable species (IUCN, 2017).

Despite being listed as a vulnerable species and its economic importance, limited studies exist on the food and feeding habits of $A$. immaculata, with no record from the Black Sea coast of Turkey. Data on diet composition are useful to understand the predator-prey relationship and identify the food preferences of a fish species. Such information can be used to assess conservative regulations and policies (Lopez-Peralta, 2002; Bandpei et al., 2012).

In this study, the diet of $A$. immaculata Bennett, 1835 was investigated in the south-east Black Sea coast of Turkey during spring, autumn and winter seasons. The dietary preferences of $A$. immaculata was also determined in relation to different length classes in order to analyse the impact of its body size on diet composition. The length-weight relationship was also derived.

\section{Materials and methods}

The study area was located around the Trabzon-Rize coast on the south-east Black Sea (Fig. 1). Specimens of A. immaculata were caught on a monthly basis from March 2012 to February 2013 across sites 1 and 2 using a commercial purse-seine with mesh size 10-16 mm. Since they migrate to rivers during summer for spawning and nursery grounds (Kottelat, 1997) and also since summer is a closed season (15 April to 1 September) in Turkish Black Sea, no specimen was procured during this period. Immediately after collection, the fish were placed in $70 \%$ alcohol and transferred to the laboratory.

In the laboratory, each specimen was weighed to the nearest $0.01 \mathrm{~g}$ and total length $\left(L_{T}\right)$ was recorded to the nearest $0.1 \mathrm{~cm}$. Based on body size, the fishes were categorised into length classes of $4 \mathrm{~cm}$ intervals. The stomach contents were recovered and identified to the 
lowest possible taxonomic level. Following Kitsos et al. (2008), the stomach fullness was categorised as empty $(0 \%)$, moderately full $(25 \%)$, half full $(50 \%)$, quite full $(75 \%)$ and very full $(100 \%)$. The contribution of each prey type in the diet of $A$. immaculata was assessed by calculating index of relative importance (\% IRI) using the formula (Cortes, 1997):

$$
\mathrm{IRI}=(\% \mathrm{~N}+\% \mathrm{~W}) \times \% \mathrm{~F}=>\% \mathrm{IRI}=\frac{\mathrm{IRI}}{\sum \mathrm{IRI}} \times 100
$$

where $\% \mathrm{~N}=$ percentage of prey groups' numerical frequency, $\% \mathrm{~W}=$ percentage of prey groups' weight and $\% \mathrm{~F}=$ percentage of prey groups' occurrence (Hyslop, 1980). Seasonal and length-based variations in the diet composition were studied through dendrogram analysis using Minitab 17 Statistical Software.

The length-weight relationship for A. immaculata was determined by log transformation of the exponential equation $\mathrm{W}=\mathrm{aL}_{\mathrm{T}}{ }^{\mathrm{b}}$ (where $a$ is the intercept and $b$ is the slope) and performing least squares regression analysis with MS Excel software. The statistical deviation of $b$ from the isometric value of 3.0 was tested by $t$-test (Pauly, 1984).

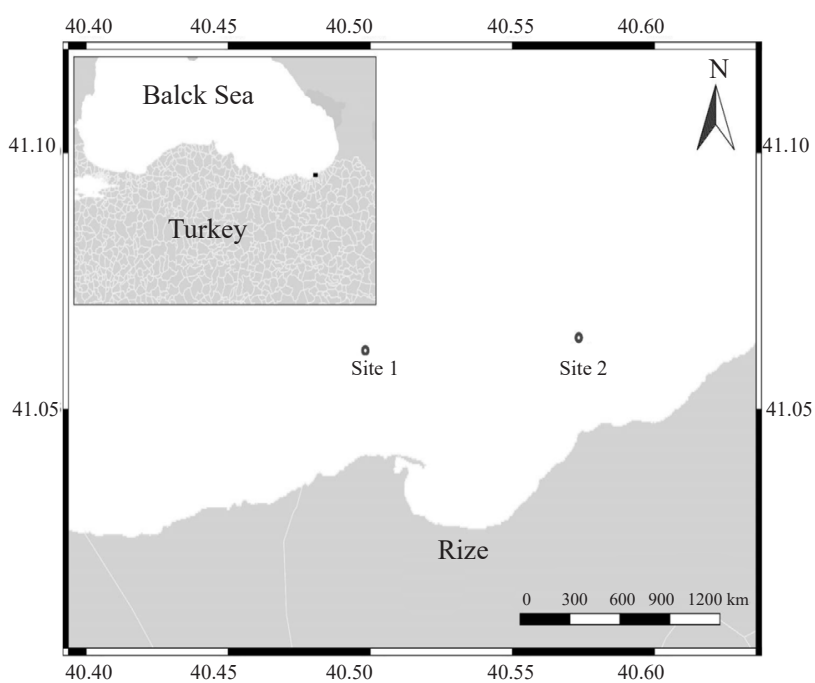

Fig. 1. Map of the study area

\section{Results}

Length frequency distribution and sex ratio

A total of 236 samples of $A$. immaculata were analysed, of which 176 were females in the size range of 13.5-32.8 cm total length $\left(L_{\mathrm{T}}\right)$ and 60 were males (12.5$\left.28.7 \mathrm{~cm} L_{\mathrm{T}}\right)$. The mean $( \pm \mathrm{S} . \mathrm{E})$ length of males $(18.2 \pm 0.6)$ was significantly smaller than that of females $(23.6 \pm 0.4)$
( $t$-test, $\mathrm{p}<0.001)$. The size-frequency distribution of females and males also significantly differed (KolmogorovSimirnov test: $\mathrm{d}=0.45985, \mathrm{p}<0.00)$. In females the dominant size was $28-30 \mathrm{~cm}$ while in males it was $18-20 \mathrm{~cm}$ (Fig. 2). The sex ratio (female: male) of $A$. immaculata in the south-east Black Sea was 1:0.34, which deviated significantly from $1: 1\left(\chi^{2}=57.02, \mathrm{p}<0.01\right)$.

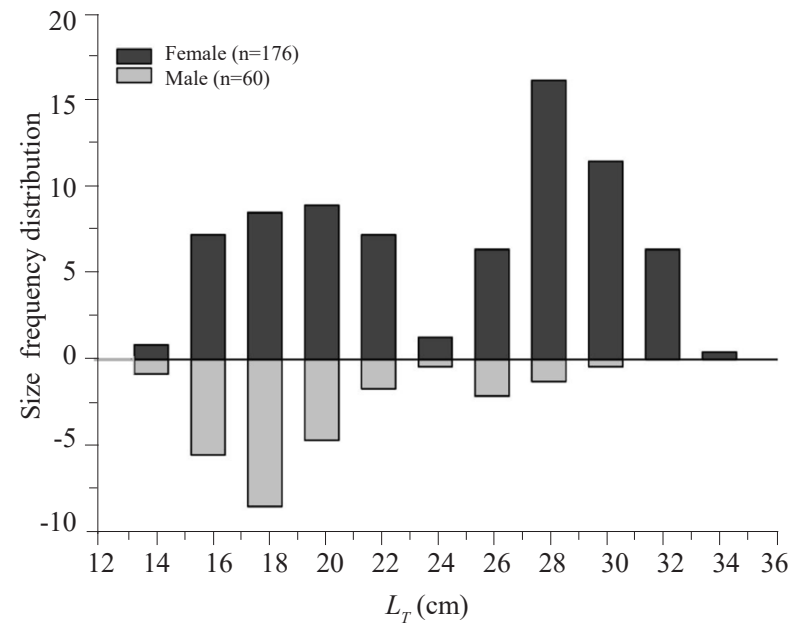

Fig. 2. Size frequency distribution of females and males of A. immaculata in the south-east Black Sea coast of Turkey (Total length, $L_{\mathrm{T}}$ )

Stomach fullness

Overall, $4.24 \%$ of the stomachs were empty, $27.54 \%$ moderately full, $25 \%$ half full, $25.42 \%$ quite full and $17.8 \%$ very full. The larger number $(>50 \%)$ of moderately full stomachs were found during winter (Fig. 3). The qualitative dietary analysis included only non-empty stomachs.

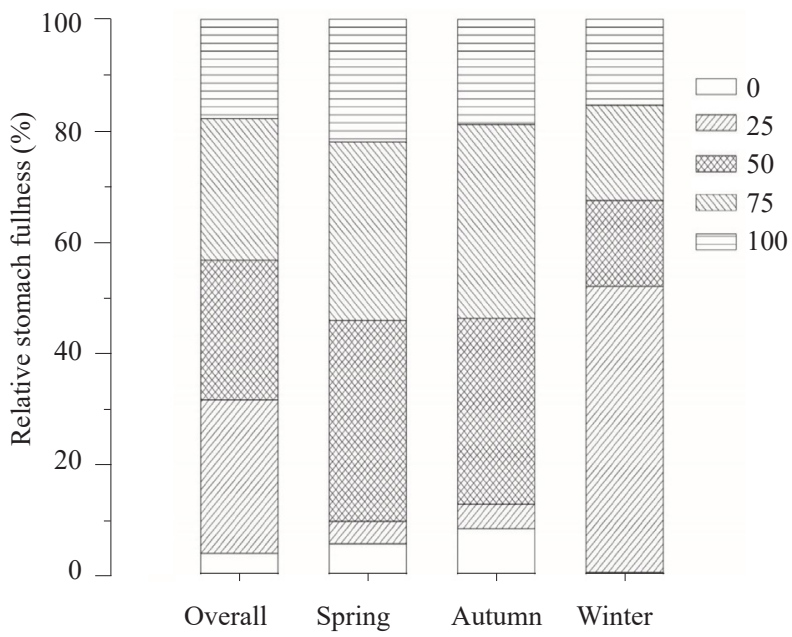

Fig. 3. Stomach fullness in A. immaculata in the south-east Black Sea coast of Turkey 


\section{Diet composition}

In all, 24 prey items were found in the stomachs of $A$. immaculata belonging to four prey categories viz., zooplankton, fish eggs (ichthyoplankton), teleostei and insecta. The Nematoda sp. represented 59.3\% IRI of the stomach contents while the second most abundant prey item was teleosts, constituting $38.2 \%$ IRI of the diet (Table 1).

Table 1. Prey categories found in the stomachs of A. immaculata in the south-east Black Sea coast of Turkey. Stomach content expressed as \% IRI

\begin{tabular}{|c|c|c|c|c|}
\hline Prey groups & $\begin{array}{l}\text { Overall } \\
(\mathrm{n}=236)\end{array}$ & $\begin{array}{l}\text { Spring } \\
(\mathrm{n}=50)\end{array}$ & $\begin{array}{l}\text { Autumn } \\
(\mathrm{n}=69)\end{array}$ & $\begin{array}{l}\text { Winter } \\
(\mathrm{n}=117)\end{array}$ \\
\hline \multicolumn{5}{|l|}{ Zooplankton } \\
\hline \multicolumn{5}{|l|}{ Arthrophoda } \\
\hline \multicolumn{5}{|l|}{ Copepoda } \\
\hline Pseudocalanus sp. & 0.0017 & 0.011 & 0.005 & \\
\hline Ostracoda & 0.0004 & 0.011 & & \\
\hline Isopoda & 0.0592 & 0.011 & 0.031 & 0.097 \\
\hline Dynamene sp. & 0.0018 & 0.047 & & \\
\hline \multicolumn{5}{|l|}{ Decapoda } \\
\hline Decapod larvae & 0.0043 & & 0.046 & \\
\hline \multicolumn{5}{|l|}{ Cumacea } \\
\hline Cumacean sp. & 0.0004 & & 0.005 & \\
\hline \multicolumn{5}{|l|}{ Amphipoda } \\
\hline Gammarus sp. & 0.0004 & & & 0.001 \\
\hline Corophium sp. & 0.0004 & & 0.005 & \\
\hline \multicolumn{5}{|l|}{ Tanaidacea } \\
\hline Tanaidacea sp. & 0.0028 & & 0.025 & \\
\hline \multicolumn{5}{|l|}{ Chaetognatha } \\
\hline Sagittwa setosa & 0.0004 & & 0.005 & \\
\hline \multicolumn{5}{|l|}{ Appendicularia } \\
\hline Oikopleura dioica & 0.0017 & & 0.021 & \\
\hline \multicolumn{5}{|l|}{ Nematoda } \\
\hline Nematoda sp. & 59.2513 & 50.64 & 37.11 & 71.555 \\
\hline \multicolumn{5}{|l|}{ Cnidaria } \\
\hline \multicolumn{5}{|l|}{ Ctenophora } \\
\hline Planula larvae & 0.0004 & & 0.005 & \\
\hline \multicolumn{5}{|l|}{ Mollusca } \\
\hline \multicolumn{5}{|l|}{ Gastropoda } \\
\hline Tricolia pullus & 0.002 & & 0.018 & \\
\hline \multicolumn{5}{|l|}{ Ichthyoplankton } \\
\hline Fish eggs & 2.0457 & 3.167 & 2.423 & 1.329 \\
\hline \multicolumn{5}{|l|}{ Teleostei } \\
\hline Engraulis encrasicolus & 24.6537 & 21.903 & 33.047 & 18.854 \\
\hline Merlangius merlangus & 0.2798 & 0.069 & 2.116 & \\
\hline Sprattus sprattus & 4.8097 & 17.009 & 3.992 & 2.881 \\
\hline Syngnathus acus & 0.0012 & 0.041 & & \\
\hline Trachurus trachurus & 8.4550 & 7.092 & 16.023 & 5.279 \\
\hline \multicolumn{5}{|l|}{ Insecta } \\
\hline Diptera sp. pupa & 0.0004 & & & 0.001 \\
\hline Diptera sp. & 0.0006 & & 0.006 & \\
\hline \multicolumn{5}{|l|}{ Others } \\
\hline Sand grains & 0.4252 & & 5.109 & \\
\hline Plastics & 0.0017 & & 0.005 & 0.001 \\
\hline
\end{tabular}

Influence of season, sex and body size on diet composition

A wide variety of prey items were found during autumn (19 prey types) followed by spring (11). In winter, only nine different prey types were recovered from the stomachs of $A$. immaculata (Table 1). The predominant prey items were Nematoda sp. and isopoda from zooplankton and Engraulis encrasicolus, Sprattus sprattus and Trachurus trachurus from teleostei. Fish eggs (ichthyoplankton) were found in all seasons. Over $92 \%$ IRI of the total stomach contents were composed of zooplankton and teleosts (Fig. 4a). The presence of plastics in the stomach contents was observed during autumn and winter while sand grains were observed only in autumn with $5.1 \%$ IRI.

Cluster analysis revealed a high percentage of similarity (79\%) between spring and winter, indicating similar diets. The spring and winter clusters were separated from autumn with $31 \%$ dissimilarity (Fig. 5a).

Female A. immaculata was found to consume a wider variety of prey items (21 prey types) than male (11 prey types). Nematoda sp. were the predominant prey group found in the stomach contents of both sexes with IRI of $52.6 \%$ for female and $75.9 \%$ for male. The other most abundant prey items were T. trachurus (8.1\% IRI), S. sprattus (7.4\% IRI) and E. encrasicolus $(7.2 \%)$ in male and E. encrasicolus (30.8\%), T. trachurus $(8.7 \%)$ and $S$. sprattus $(4.3 \%)$ in female $A$. immaculata.

The IRI of Nematoda sp. in stomach contents of smaller A. immaculata in the length classes of 12.0-15.9 and $16.0-19.9 \mathrm{~cm}$ was 80 and $74 \%$ respectively, while that of teleosts was 19.3 and $25.6 \%$ respectively (Table 2, Fig. 4b). The larger fishes (20.0-23.9 cm and above) consumed relatively higher amount of teleosts (IRI 34.1$51.2 \%$ ) than the small sized fishes. The IRI of Nematoda sp. ranged between $41.3 \%$ and $46.1 \%$ in the larger fishes. The larger fishes were also found to consume a relatively wide variety of zooplankton (Table 2).

According to dendrogram analysis, the diets of fishes in the 12.0-15.9 and 16.0-19.9 cm length classes were extremely similar $(93.75 \%$ similarity) followed by high similarity between $24.0-27.9$ and $28.0-31.9 \mathrm{~cm}$ length classes $(86.24 \%)$. These higher length classes were separated from 20.0-23.9 length class with 22.6\% dissimilarity, while the 12.0-15.9 and 16.0-19.9 length classes were separated from the others with $35.8 \%$ dissimilarity (Fig. 5b).

\section{Length-weight relationship}

The allometric coefficient $b$ was estimated for females and males separately and for sexes pooled (Table 3 ). The 


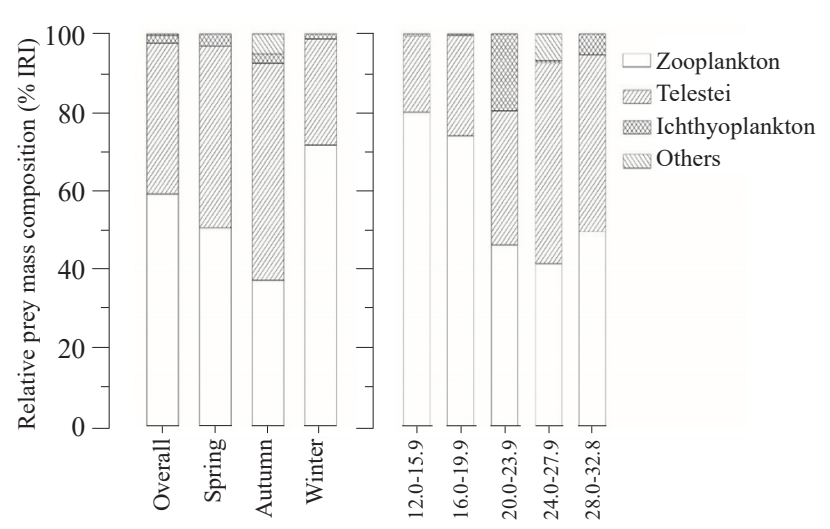

(a)

Fig. 4. Relative contribution of prey group in the stomach contents of A. immaculata in the south-east Black Sea coast of Turkey by (a) season and (b) length classes (total length, $\mathrm{cm}$ ).

estimated values of $b$ (mean $\pm 95 \%$ Confidence Interval, CI) obtained from males, females and pooled data were $3.099 \pm 0.300,3.276 \pm 0.091$ and $3.287 \pm 0.106$ respectively and were not statistically different. The value of $b$ for males did not significantly deviate from the isometric value of 3.0 while the $b$ values obtained for females and sexes pooled were found to deviate significantly from 3.0, suggesting isometric growth in males and positive allometric growth in females (Table 3).

\section{Discussion}

\section{Diet composition}

The study showed that zooplankton and teleosts together made up $97.5 \%$ IRI of the total stomach contents of $A$. immaculata. These results are in accordance with previous studies (Moskvin, 1940; Kottelat and Freyhof, 2007). The teleost species identified in the diet (Engraulis sp. and Sprattus sp.) are also found to be in line with the findings of Kottelat (1997). However, while Moskvin (1940) and Kottelat (1997) reported the main prey among zooplankton to be nekton and crustaceans, the present study recorded Nematoda sp. as the dominant zooplankton in the diet of A. immaculata. The significant contribution of nematodes in the diet of grey mullet (Osteichthyes, Mugilidae), detritivorous estuarine fishes and flounder (Platichthys flesus L.) have been reported earlier (Lasserre et al., 1976; Aarnio et al., 1996; Laffaille et al., 2002). Generally, the contribution of nematodes to the diet of fish have been underestimated (Gee, 1989). The nematodes have soft-bodies supporting their fast digestion and hence, their actual contribution to the fish diet has been underestimated (Nikolsky, 1963; Aarnio et al., 1996). According to Gee (1989) fish should be examined immediately after capture in order to assess the actual contribution of nematodes in their diet.

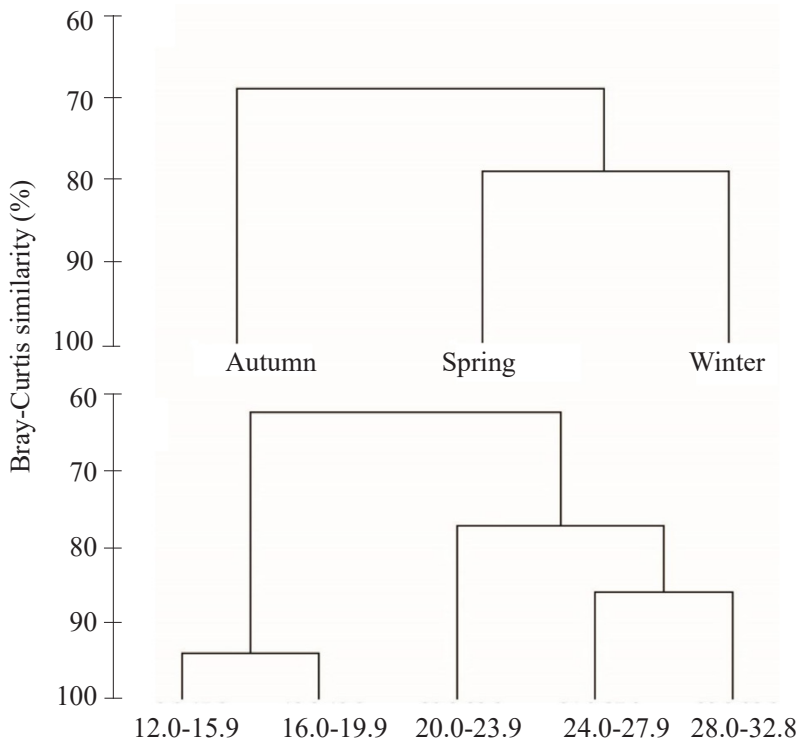

Fig. 5. Dendrogram (based on Bray-Curtis similarity method) of similarities in diet of A. immaculata in the southeast Black Sea coast of Turkey based on \% IRI across (a) seasons and (b) size (total length, $\mathrm{cm}$ )

Several studies have shown that the majority of Alosa spp. consume zooplankton and small fishes (Assis et al., 1992; Johnson and Dropkin, 1996; Kottelat and Freyhof, 2007; Azeroual, 2010) and a few of them such as Alosa kessleri and Alosa braschnikowi are known to be exclusively piscivorous having $85-98.6 \%$ of fish in the diet (Vetchanin, 1984; Coad, 1999; Bandpei et al., 2012). The presence of Nematoda sp. along with sand grains indicates that $A$. immaculata could be a bottom feeder in the sea.

In the present study, the diet of smaller size A. immaculata had a higher proportion of Nematoda sp. (74.0-80.1\%) with 19.3-25.6\% of teleosts. The larger size fishes consumed relatively more teleosts than smaller size $A$. immaculata. This could be attributed to mouth size as prey size increases with fish size (Hambright, 1991; Khan et al., 2013, 2014).

In this study, the maximum variety of different prey types in the diet of $A$. immaculata was seen during autumn. In the south-east Black Sea coast of Turkey, the diet of European anchovy, E. encrasicolus also showed a wide variety of prey types in autumn (Mazlum et al., 2017) that might indicate the maximum abundance of different prey groups during this season.

Size-frequency distribution, sex ratio and length-weight relationship

The size-frequency distribution analysis revealed that most of the specimens in females and males belong to 
Table 2. Diet compositions of $A$. immaculata in relation to sex and body size (\% IRI).

\begin{tabular}{|c|c|c|c|c|c|c|c|}
\hline \multirow[t]{2}{*}{ Prey groups } & \multicolumn{2}{|c|}{ Sex-specific diet composition } & \multicolumn{5}{|c|}{$\begin{array}{l}\text { Size-specific diet composition } \\
\text { Length classes }(\mathrm{cm})\end{array}$} \\
\hline & $\begin{array}{l}\text { Female } \\
(\mathrm{n}=176)\end{array}$ & $\begin{array}{l}\text { Male } \\
(\mathrm{n}=60)\end{array}$ & $\begin{array}{l}12-15.9 \\
(n=30)\end{array}$ & $\begin{array}{l}16-19.9 \\
(n=75)\end{array}$ & $\begin{array}{l}20-23.9 \\
(n=26)\end{array}$ & $\begin{array}{l}24-27.9 \\
(n=58)\end{array}$ & $\begin{array}{l}28-32.8 \\
(\mathrm{n}=47)\end{array}$ \\
\hline \multicolumn{8}{|l|}{ Zooplankton } \\
\hline \multicolumn{8}{|l|}{ Arthrophoda } \\
\hline \multicolumn{8}{|l|}{ Copepoda } \\
\hline Pseudocalanus sp. & 0.0008 & 0.0059 & 0.03 & & & & 0.009 \\
\hline Ostracoda & 0.0008 & & & 0.003 & & & \\
\hline Isopoda & 0.1025 & & & & 0.077 & 0.012 & 0.586 \\
\hline Dynamene sp. & & 0.0259 & & 0.004 & 0.077 & & \\
\hline \multicolumn{8}{|l|}{ Decapoda } \\
\hline Decapod larvae & 0.0074 & & & & & 0.079 & \\
\hline \multicolumn{8}{|l|}{ Cumacea } \\
\hline Cumacean sp. & 0.0008 & & & & & & 0.009 \\
\hline \multicolumn{8}{|l|}{ Amphipoda } \\
\hline Gammarus sp. & 0.0008 & & & & & & 0.009 \\
\hline Corophium sp. & 0.0008 & & & & & & 0.009 \\
\hline \multicolumn{8}{|l|}{ Tanaidacea } \\
\hline Tanaidacea $s p$. & 0.0045 & & & & & & 0.038 \\
\hline \multicolumn{8}{|l|}{ Chaetognatha } \\
\hline Sagitta setosa & 0.0008 & & & & & & 0.009 \\
\hline \multicolumn{8}{|l|}{ Appendicularia } \\
\hline Oikopleura dioica & 0.0031 & & & & & & 0.034 \\
\hline \multicolumn{8}{|l|}{ Nematoda } \\
\hline Nematoda sp. & 52.5715 & 75.9472 & 80.075 & 74.022 & 46.103 & 41.340 & 43.394 \\
\hline \multicolumn{8}{|l|}{ Cnidaria } \\
\hline \multicolumn{8}{|l|}{ Ctenophora } \\
\hline Planula larvae & 0.0008 & & & & & 0.009 & \\
\hline \multicolumn{8}{|l|}{ Mollusca } \\
\hline \multicolumn{8}{|l|}{ Gastropoda } \\
\hline Tricolia pullus & & 0.0449 & & & & & \\
\hline \multicolumn{8}{|l|}{ Ichthyoplankton } \\
\hline Fish eggs & 2.8038 & 0.4265 & 0.546 & 0.375 & 19.496 & 0.483 & 7.754 \\
\hline \multicolumn{8}{|l|}{ Teleoste1 } \\
\hline E. encrasicolus & 30.8048 & 7.1746 & 11.680 & 12.606 & 25.810 & 27.505 & 31.476 \\
\hline M. merlangus & 0.2378 & 0.4582 & & 0.03 & & 1.258 & 0.531 \\
\hline S. sprattus & 4.3132 & 7.3938 & 7.113 & 9.071 & 6.653 & 4.972 & 1.28 \\
\hline Syngnathus acus & & 0.0251 & & 0.017 & & & \\
\hline T. trachurus & 8.7150 & 8.0876 & 0.556 & 3.868 & 1.706 & 17.513 & 14.843 \\
\hline \multicolumn{8}{|l|}{ Insecta } \\
\hline Diptera sp. pupa & 0.0008 & & & & & 0.009 & \\
\hline Diptera sp. & 0.0010 & & & & & & 0.009 \\
\hline \multicolumn{8}{|l|}{ Others } \\
\hline Sand grains & 0.4261 & 0.4102 & & & 0.077 & 6.790 & \\
\hline Plastics & 0.0031 & & & 0.003 & & & 0.009 \\
\hline
\end{tabular}

28-30 and 18-20 cm length classes respectively, which are consistent with the findings of Yilmaz and Polat (2011). They reported the dominant size group as $31 \mathrm{~cm}$ for females and $17 \mathrm{~cm}$ for males.
In this study, the sex ratio of $A$. immaculata significantly deviated from 1:1 which is in line with the sex ratio of 1:0.67 reported by Y1lmaz and Polat (2011). However, Erguden et al. (2011) reported a sex ratio of 
Table 3. Comparison of parameters of the length-weight relationship (LWR) for A. immaculata from the south-east Black Sea coast, with estimates from earlier studies

\begin{tabular}{|c|c|c|c|c|c|c|c|c|c|}
\hline \multirow{2}{*}{ Sex } & \multicolumn{2}{|c|}{ Total length (cm) } & \multicolumn{7}{|c|}{ Parameters of $L W R$} \\
\hline & $\mathrm{n}$ & Min-Max & $a$ & $b$ & $95 \% \mathrm{CI}(b)$ & $r^{2}$ & Pauly $t$-test & $\mathrm{p}$ & Reference \\
\hline $\bar{q}$ & 176 & $13.5-32.8$ & 0.003 & 3.276 & 0.091 & 0.966 & 5.992 & $<0.001$ & Present study \\
\hline o & 60 & $12.5-28.7$ & 0.006 & 3.099 & 0.300 & 0.908 & 0.745 & $>0.05$ & \\
\hline $\mathrm{B}$ & 236 & $12.5-32.8$ & 0.003 & 3.287 & 0.106 & 0.963 & 6.317 & $<0.001$ & \\
\hline o & 438 & $10.2-38.8$ & 0.003 & 3.303 & 0.027 & 0.993 & - & $<0.05^{*}$ & Yilmaz and Polat (2011) \\
\hline$\hat{\sigma}$ & 292 & $11.4-35.5$ & 0.004 & 3.249 & 0.037 & 0.990 & - & $<0.05^{*}$ & \\
\hline B & 730 & $10.2-38.8$ & 0.003 & 3.285 & 0.021 & 0.992 & - & $<0.05^{*}$ & \\
\hline q & 294 & $14.0-34.2$ & 0.010 & 2.970 & 0.066 & 0.955 & - & - & Erguden et al. (2011) \\
\hline $0^{\pi}$ & 273 & $13.2-34.1$ & 0.007 & 3.070 & 0.079 & 0.951 & - & - & \\
\hline $\mathrm{B}$ & 567 & $13.2-34.2$ & 0.008 & 3.040 & 0.050 & 0.952 & - & - & \\
\hline q & 1039 & $11.6-31.2$ & 0.021 & 3.390 & - & 0.984 & - & - & Samsun (1995) \\
\hline$\hat{\sigma}$ & 851 & $11.0-31.6$ & 0.025 & 3.340 & - & 0.979 & - & - & \\
\hline B & 1890 & $11.6-31.6$ & 0.002 & 3.390 & - & 0.983 & - & - & \\
\hline $\mathrm{B}$ & - & $9.0-36.0$ & 0.063 & 2.550 & - & - & - & - & Kolarov (1991) \\
\hline $\mathrm{B}$ & 191 & $24.2-37.7$ & 0.071 & 2.488 & - & 0.780 & - & $0.03^{*}$ & Yankova et al. (2011) \\
\hline
\end{tabular}

n: Number of specimens measured, B: both sexes; *: significant

1:0.93 for $A$. immaculata that did not reflect a significant deviation from $1: 1$

The present study suggested a positive allometric growth for females and for sexes pooled data (including males and females) which was consistent with other studies from the Black Sea (Samsun, 1995; Erguden et al., 2011; Y1lmaz and Polat, 2011). However, in the present study, male $A$. immaculata exhibited an isometric growth pattern, which might be the result of a smaller sample size $(n=60)$ for males. Interestingly, some studies from Bulgarian waters have also reported negative allometric growth in this species (Kolarov, 1991; Yankova et al., 2011).

\section{References}

Aarnio, K., Bonsdorff, E. and Rosenback, N. 1996. Food and feeding habits of juvenile flounder Platichthys flesus (L.), and turbot Scophthalmus maximus L. in the Aland Archipelago, northern Baltic Sea. J. Sea Res., 36: 311-320.

Aprahamian, M. W., Aprahamian, C. D., Bagliniere, J. L., Sabatie, R. and Alexandrino, P. 2003. Alosa alosa and Alosa fallax spp.: literature review and bibliography. $R$ and D Technical Report W1-014/TR. Environment Agency, Warrington, UK, 349 pp.

Assis, C., Almeida, P., Moreira, F., Costa, J. and Costa, M. 1992. Diet of the twaite shad Alosa fallax (Lacepede) (Clupeidae) in the River Tagus Estuary, Portugal. J. Fish Biol., 41: 1049-1050. DOI: 10.1111/j.1095-8649.1992.tb02734.x.

Azeroual. A. 2010. Alosa alosa. The IUCN Red List of Threatened Species 2010: e.T903A13090693 (Accessed 14 March 2017).

Bandpei, M., El-Sayed, A., Pourgholam, R., Nasrolahzadeh, H. and Valinassab, T. 2012. Food and feeding habits of the
Caspian marine shad Alosa braschnikowi (Clupeidae) in the southern Caspian Sea. Cybium, 36: 411-416.

Coad, B. W. 1999. Freshwater fishes of Iran. www.briancoad. com, version (08/12/2016) (Accessed 14 March 2017).

Cortes, E. 1997. A critical review of methods of studying fish feeding based on analysis of stomach contents: application to elasmobranch fishes. Can. J. Fish Aquat. Sci., 54: 726-738. DOI: 10.1139/cjfas-54-3-726.

Erguden, D., Turan, F. and Turan, C. 2011. Length-weight and length-length relationships for four shad species along the western Black Sea coast of Turkey. J. Appl. Ichthyol., 27: 942-944. doi: 10.1111/j.1439-0426.2010.01589.x.

Freyhof, J. R. and Kottelat, M. 2008. Alosa immaculata The IUCN Red List of Threatened Species, 2008:e. T907A13093654. http://dx.doi.org/10.2305/IUCN.UK. 2008. RLTS.T907A13093654.en. (Accessed 22 March 2017).

Gee, J. 1989. An ecological and economic review of meiofauna as food for fish. Zool. J. Linn. Soc., 96: 243-361. doi.org/10.1111/j.1096-3642.1989.tb02259.x.

Hambright, K. D. 1991. Experimental analysis of prey selection by largemouth bass: role of predator mouth width and prey body depth. Trans. Am. Fish Soc., 120: 500-508. doi. org/10.1577/1548-8659(1991)120<0500:EAOPSB >2.3.CO;2.

Hyslop, E. 1980. Stomach contents analysis - a review of methods and their application. J. Fish Biol., 17: 411-429. DOI : 10.1111/j.1095-8649.1980.tb02775.x.

IUCN 2017. Red List of Threatened Species. www.iucnredlist. org, version (2016-3). (Accessed 22 March 2017).

Johnson, J. and Dropkin, D. 1996. Feeding ecology of larval and juvenile American shad (Alosa sapidissima) in a small pond. J. Appl. Ichthyol., 12: 9-13. 
Juanes, F., Marks, R. E., McKown, K. A. and Conover, D. O. 1993. Predation by age- 0 bluefish on age- 0 anadromous fishes in the Hudson River Estuary. Trans. Am. Fish. Soc., 122: $348-356$

Khan, U., Hasan, Z., Inayatullah, M. and Jan, A. 2013. Analysis of stomach contents of freshwater catfish, Eutropiichthys vacua (Hamilton, 1822) from Khyber Pakhtunkhwa rivers, Pakistan. Pak. J. Zool., 45: 1153-1156.

Khan. U., Hasan, Z., Inayatullah, M. and Jan, A. 2014. Feeding habits of a freshwater catfish, Clupisoma naziri (Pisces: Schilbidae) from Khyber Pakhtunkhwa rivers, Pakistan. Pak. J. Zool., 46: 1166-1169.

Kitsos, M. S., Tzomos, T., Anagnostopoulou, L. and Koukouras, A. 2008. Diet composition of the seahorses, Hippocampus guttulatus Cuvier, 1829 and Hippocampus hippocampus (L., 1758) (Teleostei, Syngnathidae) in the Aegean Sea. J. Fish Biol., 72: 1259-1267. doi.org/10.1111/j.10958649.2007.01789.x.

Kolarov, P. 1991. Alosa pontica pontica (Eichwald, 1938). In: Hoestlandt, H. (Ed.), The freshwater fishes of Europe, vol. 2: Clupeidae, Anguillidae. AULA-Verlag, Wiesbaden, Germany, p. 337-368.

Kottelat, M. 1997. European freshwater fishes. Biologia, 52, Suppl. 5: 1-271.

Kottelat, M. and Freyhof, J. 2007. Handbook of European freshwater fishes. Publications Kottelat, Cornol, Switzerland, $646 \mathrm{pp}$.

Laffaille, P., Feunteun, E., Lefebvre, C., Radureau, A., Sagan, G. and Lefeuvre, J. C. 2002. Can thin-lipped mullet directly exploit the primary and detritic production of European macrotidal salt marshes? Estuar. Coast Shelf Sci., 54: 729736 .

Lasserre, P., Renaud-Mornant, J. and Castel, J. 1976. Metabolic activities of meiofaunal communities in a semi-enclosed lagoon: possibilities of trophic competition between meiofauna and mugilid fish In: Persoone, G. (Ed.), Proceedings of the $10^{\text {th }}$ European Symposium on Marine Biology 2, Population dynamics of marine organisms in relation with nutrient cycling in shallow waters, 17-23 September 1975, Ostend, Belgium, p. 393-414.

Lenhardt, M., Visnjic-Jeftic, Z., Navodaru, I., Jaric, I., Vassilev, M., Gacic, Z. and Nikcevic, M. 2012. Fish stock management cooperation in the lower Danube region: A case study of sturgeons and pontic shad. In: Lagutov, V. (Ed.), Environmental security in watersheds: The sea of Azov. Springer, Netherlands, p. 127-140.
Lopez-Peralta, R. H. and Arcila, C. A. T. 2002. Diet composition of fish species from the southern continental shelf of Colombia. Naga World Fish Center Q., 25: 23-29.

Mazlum, R. E., Solak, E. and Bilgin, S. 2017. Size and seasonal diet variation of European anchovy Engraulis encrasicolus (Linnaeus, 1758) in the south-east Black Sea. Cah. Biol. Mar., 58(3): 251-260. DOI: 10.21411/CBM.A.B2C2DBE2.

Moskvin, B. S. 1940. Materials on the feeding of shads in the north-eastern part of the Black Sea. Tr. Novoross. Biol. Sta., 2(3): 259-272. www.fishbase.org. (Accessed 22 March 2017).

Navodaru, I. and Waldman, J. R. 2003. Shads of eastern Europe from the Black Sea: Review of species and fisheries. In: Limburg, K. E. and Waldman, J. R. (Eds). Biodiversity, status and conservation of the world's shads. Proceedings of the International Conference on Status and Conservation of Shads World Wide. vol. 35. American Fisheries Society. Bethesda, Maryland, USA, p. 69-76.

Nikolsky, G. V. 1963. The ecology of fishes. Academic Press, New York, USA, 352 pp.

Pauly, D. 1984. Fish population dynamics in tropical waters: a manual for use with programmable calculators. ICLARM Stud. Rev., 8: 325 pp.

Raykov, V. S. and Triantaphyllidis, G. V. 2015. Review of driftnet fisheries in Bulgarian marine and inland waters. J. Aquac. Mar. Biol., 2(2): 1-10.

Samsun, O. 1995. The weight-length relationship of the shads Alosa pontica Eichwald, 1938 in the mid of the Turkish Black Sea. E.U. Su Urunleri Dergisi, 12: 15-21 (in Turkish).

TUIK 2015. State Fisheries Statistics. Ankara, Turkey. http:// www.tuik.gov.tr/PreTablo.do\%3Falt_id=47. (Accessed 22 March 2017).

Vetchanin, V. 1984. Feeding of the astrakhan shad, Alosa brasnikovi (Clupeidae), in the south-eastern Caspian Sea. J. Ichthyol., 24: 143-147.

Yankova, M., Pavlov, D., Raykov, V., Mihneva, V. and Radu, G. 2011. Length-weight relationships of ten fish species from the Bulgarian Black Sea waters. Turk. J. Zool., 35: 265-270. doi:10.3906/zoo-0912-44.

Yilmaz, S. and Polat, N. 2011. Length-weight relationship and condition factor of pontic shad, Alosa immaculata (Pisces: Clupeidae) from the southern Black Sea. Res. J. Fish Hydrobiol., 6: 49-53. 